\section{LAS ESTAMPAS QUE ILUSTRAN ALGUNOS LIBROS RELIGIOSOS DE LA IMPRENTA DE PUEBLA (NUEVA ESPAÑA) DE PEDRO DE}

\section{LA ROSA}

THE ENGRAVING THAT ILLUSTRATED SOME RELIGIOUS BOOKS OF THE PRESS OF PUEBLA (NEW SPAIN) OF PEDRO DE LA ROSA

LES ESTAMPES QUI ILLUSTRENT QUELQUES LIVRES RELIGIEUX DE LA PRESSE DE PUEBLA (NOUVELLE ESPAGNE) DE PEDRO DE LA ROSA

RESUMEN: En el presente artículo abordamos el estudio de las estampas que ilustran algunos de los libros salidos de una de las más importantes imprentas poblanas (México) de finales del siglo XVIII e inicios del XIX, la de Pedro de la Rosa. Todas ellas tienen motivos religiosos vinculados a los contenidos de los libros que decoran o a los autores de los mismos. La mayoría de estas estampas son anónimas, aunque encontramos algunas firmadas por Manuel Galicia Villavicencio y José de Nava, a quien además atribuimos otra estampa carente de firma.

PALABRAS CLAVE: Pedro de la Rosa; Puebla de los Ángeles; Nueva España; imprenta; estampa; entalladura.
ABSTRACT: In this article we study of the engravings which illustrate some of the books that came out of one of most important presses poblanas (Mexico) of the late eighteenth and early nineteenth century, of the Pedro de la Rosa. All of them have religious motifs linked to the contents of the books they decorate or the authors of them. The majority of the engravings are anonymus, although we find some signed by Manuel Galicia Villavicencio and Jose de Nava, to whom we also attribute some lacking signature.

KEYWORDS: Pedro de la Rosa; Puebla de los Ángeles; New Spain; press; engraving; woodcuts.
RÉSUMÉ: Dans cet article nous étudions les estampes qui illustrent des livres imprimés par l'une des presses plus importantes à Puebla (Mexique) à la fin du XVIIlème et début du XIXème siècle, la de Pedro de la Rosa. Ces estampes sont des motifs religieux liés aux contenus des livres qui ornent ou avec les auteurs de ceux-ci. La majorité des estampes sont anonymes, mais nous trouvons certaines signées par Manuel Galicia Villavicencio et Jose de Nava, à qui nous attribuons autre gravure sans signature.

MOTS-CLÉS: Pedro de la Rosa; Puebla de los Ángeles; Nouvelle Espagne; press; estampes; gravure sur bois.

\section{CALVO PORTELA, Juan Isaac}

Instituto de Investigaciones Estéticas

Universidad Nacional Autónoma de México

Instituto de Investigaciones Estéticas Circuito Mario de la Cueva, s.n. Ciudad Universitaria, Coyoacán 04510 México D. F.

Juanlscportel6@hotmail.com

ORCID ID: 0000-0002-2565-2166

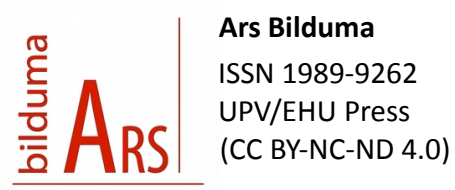

101

https://doi.org/10.1387/ars-bilduma.17872 BIBLID [(2018), 8; 101-119]

Recep.: 23/05/2017 Acept.: 30/05/2017 


\section{INTRODUCCIÓN}

La imprenta de Pedro de la Rosa en Puebla de los Ángeles fue indudablemente la más importante de dicha ciudad y una de las más activas en el Virreinato de la Nueva España en el último tercio del siglo XVIII y en las primeras décadas de la siguiente centuria. En 1777 apareció por vez primera un libro con su pie de imprenta, "Oficina Nueva Matritense. En el Portal de las Flores" ${ }^{1}$. Sin embargo, como ha señalado Garone, posiblemente su actividad tipográfica se remonta a unos años antes; en 1773, a la muerte de su suegro el también impresor Cristóbal Tadeo Ortega, asumió un papel preponderante en su imprenta, llamada de los Herederos de la Viuda de Ortega ${ }^{2}$. José Toribio Medina en su monumental trabajo sobre la imprenta poblana, dio a entender que se trató de un único impresor que estuvo activo más de cincuenta años ${ }^{3}$, pues algunos de sus últimos impresos son de la década de 1820, cuando México ya se había independizado del dominio español. Sin embargo, esta teoría ya fue rechazada por Quintana, que considera que a lo largo de estos años la imprenta estuvo dirigida por distintos familiares, aunque no aporta documentación, ni señala quienes fueron dichos familiares ${ }^{4}$. Pérez Salazar considera que el taller fue dirigido primero por Pedro de la Rosa y posteriormente por su hijo Pedro Pascual de la Rosa, fruto de su segundo

1 PÉREZ SALAZAR, F.: El grabado en la ciudad de Puebla de los Ángeles. Puebla, Gobierno del Estado de Puebla, Secretaria de Cultura, 1990, p. 80; GARONE GRAVIER, M.: Historia de la imprenta y la tipografía colonial en Puebla de los Ángeles. Ciudad de México, UNAM, Instituto de Investigaciones Bibliográficas, 2014, p. 434.

2 Ibídem, p. 430.

3 MEDINA, J. T.: La imprenta en la Puebla de los Ángeles. Ciudad de México, Universidad Nacional Autónoma de México, 1991, p. XL.

4 QUINTANA, J. M.: Las artes gráficas en Puebla. México, Antigua Librería Robredo, 1960, p. 15. matrimonio con Mariana de la Carrera ${ }^{5}$, hipótesis que ha sido corroborada por Marina Garone en su reciente trabajo sobre la imprenta poblana en el período colonial ${ }^{6}$. Todos los libros a los que nos vamos a referir en este artículo, fueron impresos por el propio Pedro de la Rosa, aunque es muy posible que su hijo colaborase con él en la realización de los mismos, puesto que se formó en el taller familiar.

En ningún caso podemos considerar a Pedro de la Rosa un simple impresor, sino que fue un hábil empresario sumamente polifacético, como demuestran algunos de los hechos que marcaron su vida. Quizás el más conocido fue el pleito que mantuvo con los Colegios de san Pedro y san Pablo de Puebla, por el privilegio que tenía su hija María Manuela de la Rosa y Ortega, fruto de su primer matrimonio con María de la Luz Ortega, como heredera de los Ortega, para la impresión de convites en dicha ciudad $^{7}$. En el año 1782 recibió el arrendamiento de otro privilegio correspondiente al Hospital General de los Naturales en la Ciudad de México, para la impresión de los catecismos y doctrinas ${ }^{8}$, lo que demuestra que expandió su negocio a la capital virreinal. Este privilegio fue renovado en varias ocasiones hasta principios de la siguiente centuria.

En el colofón del libro de Juan Antonio González de la Zarza, Siestas dogmáticas en las que con un estilo dulce, claro y llano por un niño es instruido un ranchero en las quatro partes principales de la doctrina

5 PÉREZ SALAZAR, F.: op. cit., p. 83

6 GARONE GRAVIER, M.: op. cit., pp. 430-432.

7 PÉREZ SALAZAR, F.: op. cit., p. 80; GARONE GRAVIER, M.: op. cit., pp. 431-432.

8 PÉREZ SALAZAR, F.: op. cit., p. 81; MARTíNEZ PEÑALOZA, T.: “Atisbos del barroco mexicano", Imprentas, ediciones y grabados de México Barroco. Puebla, Museo Amparo, 1995, p. 49; GARONE GRAVIER, M.: op. cit., p. 434. 
christiana, reimpreso por Pedro de la Rosa en $1781^{9}$, hallamos una relación de los libros que se vendían en su negocio en el Portal de las Flores, entre los que se incluyen tanto libros salidos de sus prensas como los de otras imprentas tanto virreinales como españolas, entre los que se comprenden los libros del Nuevo Rezado. Al final de esta relación se indica que también se vendían "estampas de santos de todos los tamaños" ${ }^{10}$. La escasa información que aporta sobre las mismas, nos lleva a pensar que se trataba de estampas devocionales que circularon enormemente por todo el Virreinato durante el siglo XVIII, aunque no indica cuales son los santos representados, a que artistas se deben o si fue él mismo quien las editó. En cualquier caso, para Pedro de la Rosa este comercio de estampas devocionales debía de tener cierta importancia y demuestra la diversificación de su negocio.

Todos los libros a los que nos vamos a referir son de temática religiosa, como la mayor parte de la producción de Pedro de la Rosa, aunque no toda, como se desprende del trabajo de Toribio Medina. Esta fue una característica común a todos los impresores novohispanos del siglo XVIII, tanto los asentados en México como en Puebla de los Ángeles. Siguiendo la clasificación establecida por Pierre Ragon de los libros religiosos impresos en la Nueva España, los que vamos a estudiar podríamos incluirlos en los grupos tercero y cuarto, es decir, aquellos dedicados a los intercesores, fundamentalmente a Cristo y la Virgen, y en menor medida los santos, y los libros de ejercicios piadosos y espirituales ${ }^{11}$. Las estampas que ilustran

9 Biblioteca Miguel Lerdo de Tejada, 200/ICC6.

10 GONZÁLEZ DE LA ZARZA, J. A.: Siestas dogmáticas en las que con un estilo dulce, claro y llano por un niño es instruido un ranchero en las quatro partes principales de la doctrina christiana. Puebla, Imprenta de Pedro de la Rosa, sin paginar.

11 RAGON, P.: "Imprentas coloniales e historia de las devociones en México (Siglos XVII y XVIII)", REDIAL: revista europea de información y documentación sobre América Latina, estos libros fueron abiertas tanto por el procedimiento de la entalladura como de la talla dulce, demostrando cómo la introducción de este procedimiento a fines del siglo XVII en Puebla por Miguel Amat ${ }^{12}$, no hizo desaparecer la entalladura. Esto nos lleva a afirmar que a lo largo de la centuria se produjo una convivencia de ambos procedimientos del grabado. La mayoría de estas estampas carecen de las firmas del inventor, dibujante, grabador y editor, aunque tres de ellas presentan las firmas de los grabadores, una del grabador mexicano Manuel Galicia de Villavicencio y otras dos del poblano José de Nava.

\section{ESTUDIO ICONOGRÁFICO DE LAS ESTAMPAS}

La primera estampa a la que nos vamos a referir ilustra el libro de fray Juan de Abreu, miembro de la Orden Tercera Franciscana en Ciudad de México, Desagravios dolorosos de la Santísima Virgen María Nuestra Señora, por

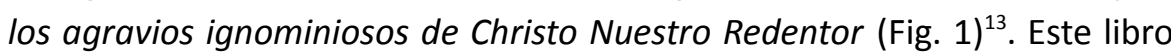
no tiene el pie de imprenta de Pedro de la Rosa, sino de los herederos de la viuda de Miguel Ortega, pero he decidido incluirlo porque para el año 1774 este impresor ya jugaba un papel crucial en dicha imprenta. Este libro hay que enmarcarlo en la literatura devocional dedicada a los dolores de la Virgen que va a tener un gran desarrollo a lo largo del siglo XVIII en la literatura religiosa novohispana ${ }^{14}$.

№ 8-9, 1998, p. 34.

12 PÉREZ SALAZAR, F.: op. cit., pp. 15-16.

13 Biblioteca Nacional de México (desde ahora BNM), Fondo Reservado, RSM 1774 P6ABR.

14 RAGON, P.: op. cit., p. 39. 


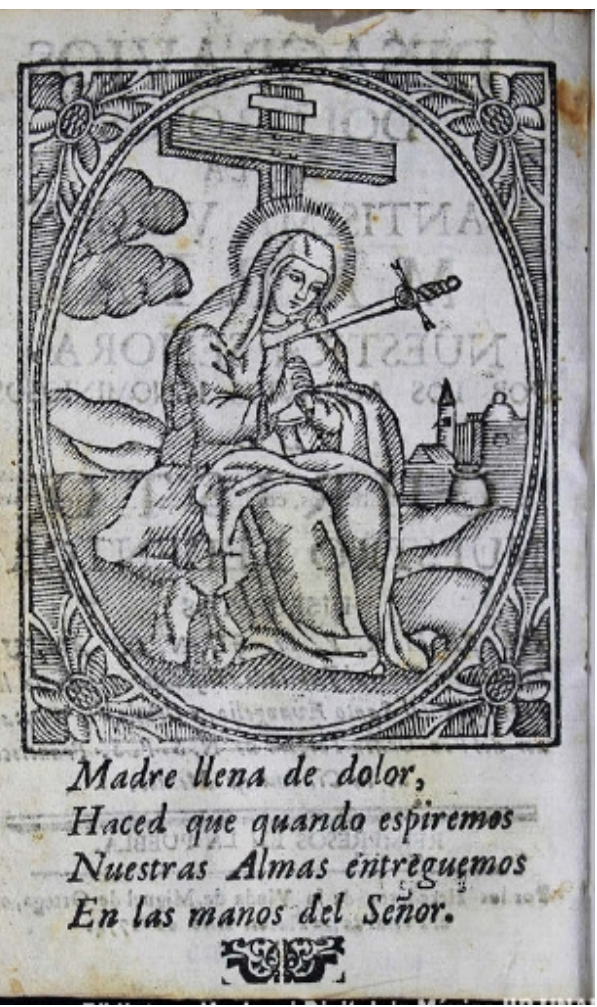

Fig. 1: Virgen de los Dolores, en Desagravios dolorosos de la Santísima Virgen María Nuestra Señora, por los agravios ignominiosos de Christo Nuestro Redentor, 1774. Biblioteca Nacional de México
Esta entalladura anónima se dispone en el verso del folio de la portada tipográfica, precediendo al prólogo al lector $^{15}$. Bajo ella leemos estos versos que aluden al carácter de intercesora de la Virgen:

\section{"Madre llena de dolor, \\ Haced que quando espiremos \\ Nuestras almas entreguemos \\ En las manos del Señor".}

La estampa tiene un marco rectangular que envuelve un óvalo en el que vemos a la Virgen de los Dolores; en las enjutas se disponen unas flores muy esquemáticas. La elección del motivo está claramente vinculada al propio contenido del libro como se desprende del Prólogo al Lector $^{16}$. La representación de la Virgen de los Dolores va a ser muy frecuente en la Nueva España desde el último tercio de la anterior centuria y la volvemos a encontrar en otras estampas que ilustran libros de la imprenta de Pedro de la Rosa. Los jesuitas tuvieron un papel fundamental en la introducción del

$1580 \times 102 \mathrm{~mm}$.

16 DE ABREU, J.: Desagravios dolorosos de la Santísima Virgen María Nuestra Señora, por los agravios ignominiosos de Christo Nuestro Redentor, "Prólogo al lector". Puebla de los Ángeles, Imprenta de los herederos de la viuda de Miguel Ortega, 1774, sin paginar. fervor por esta devoción mariana, en 1673 el jesuita José Vidal fundó la primera congregación dedicada a la misma en Ciudad de México ${ }^{17}$. En realidad, la Compañía de Jesús va a tener un rol muy notable en la difusión de muchas de las advocaciones marianas en el Virreinato de la Nueva España ${ }^{18}$. Sin embargo, como muchas de ellas el culto a la Virgen Dolorosa tuvo su origen en Europa en la Edad Media, concretamente en la Toscana en el siglo XIII, siendo los Servitas los primeros en defenderla.

La Virgen está sentada a los pies de la cruz, dispuesta de tres cuartos hacia la derecha, une sus manos a la altura del pecho e inclina suavemente la cabeza. En su torso vemos la espada que haría referencia a la profecía del sacerdote Simeón, recogida por el evangelista Lucas ${ }^{19}$. Hay una clara desproporción entre la figura de la Virgen y la cruz dispuesta tras ella. Al fondo atisbamos un paisaje con unas colinas a la izquierda y una ciudad a la derecha que sería Jerusalén. En la parte superior izquierda hay unas nubes que quizás aluden a las tinieblas que envolvieron la tierra tras la crucifixión de Cristo.

17 GONZALBO AIZPURU, P.: "Las devociones marianas en la vieja provincia de la Compañia de Jesús", en Manifestaciones religiosas en el mundo colonial americano, Vol. 2 Mujeres, instituciones y culto a María. Ciudad de México, Universidad Iberoamericana, INAH, Codumex, 1994, p. 115; BARGELLINI, Cl.: "Jesuits devotions and Retablos in New Spain", en The Jesuits. Cultures, Sciences and the Arts. 1540-1773. Toronto, University of Toronto Press, 2000, p. 687; CASTILLO OREJA, M. Á.; GORDO PÉLAEZ, L. J.: “Versos e imágenes: culto y devociones marianas en el templo de la Compañía de Jesús en Zacatecas, México", Anales de Historia del Arte, 2008, no extraordinario, p. 322.

18 Para ello ver los trabajos de BARGELLINI, Cl.: op. cit., pp. 680-698; y "El arte en las misiones del norte de la Nueva España”, en el catálogo de la exposición El arte en las misiones del Norte de la Nueva España. Ciudad de México, Antiguo Colegio de san Ildefonso, 2009, pp. 54-93.

19 Lc. $2,35$. 


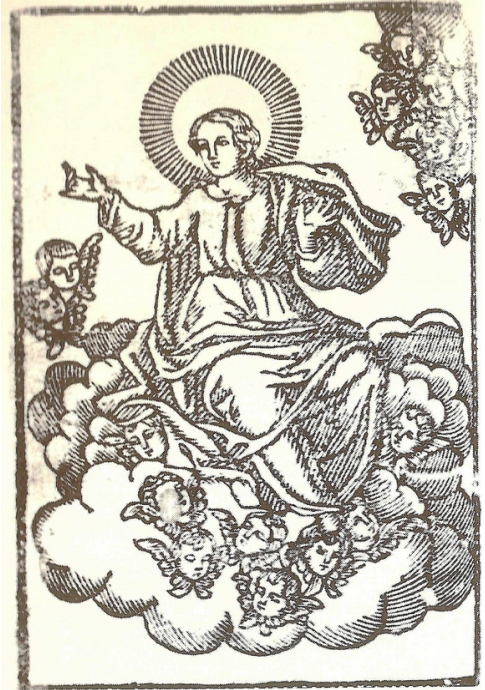

Fig. 2: Asunción de la Virgen, en Clamores y llantos del hijo pródigo o afectos de una alma penitente y convertida a Dios, de Vicente Negri, 1778

Biblioteca Nacional de México

Desde el punto de vista técnico no se puede considerar una obra de gran calidad, aunque el artista, o mejor dicho el artesano que la abrió, demuestra dominar las gubias dando la sensación de profundidad al paisaje y volumen a los vestidos de la Virgen.

La siguiente estampa ilustra la traducción que hizo Tomás Ruselmi del libro de Vicente Negri, Clamores y llantos del hijo pródigo o afectos de una alma penitente y convertida a Dios (Fig. 2) ${ }^{20}$. A diferencia del anterior libro, éste si tiene el pie de imprenta de Pedro de la Rosa y está fechado en 1778. Nuevamente se trata de una entalladura anónima. El hecho de que el libro esté dedicado a la Virgen del Buen Consejo, ha llevado a que algunos consideren que en esta entalladura se representa dicha advocación mariana ${ }^{21}$, aunque el tipo iconográfico que se sigue es el de la Asunción de la Virgen, como la describe Pacheco en su tratado ${ }^{22}$.

La elección de este motivo no resulta extraña, teniendo en cuenta el enorme impulso que tuvo en el arte español y novohispano desde el

20 BNM, Fondo Reservado, RSM 1778 P6NEG, 61×85 mm.

21 GARONE, M.: op. cit., p. 469

22 PACHECO, F.: Arte de la pintura. Sevilla, Simón Faxardo, 1649, p. 549.
Concilio de Trento. El origen de esta doctrina se remonta a la Edad Media, según Réau al siglo XIII' ${ }^{23}$ y su desarrollo histórico va a estar muy unido al de la doctrina inmaculista. Alonso de Villegas en su Flos Sanctorum, asegura que los decretos conciliares daban a entender una vinculación entre ambas doctrinas ${ }^{24}$, y en la misma línea se expresó Pedro de Ribadeneira, al tratar sobre la fiesta de la Asunción ${ }^{25}$. Aunque ninguna de ellas fueron reconocidas como dogmas de fe hasta 1854, el de la Inmaculada, y 1950, el de la Asunción. Esta relación va a tener su plasmación en el mundo hispánico no sólo en las artes visuales, sino también en la producción literaria y homilética ${ }^{26}$.

La escena tiene lugar en un espacio indefinido, en el que únicamente observamos unas nubes en las que está sentada la Virgen con un fuerte movimiento en su cuerpo, pues las piernas están orientadas hacia la derecha, mientras que la parte superior de su cuerpo está vuelto hacia la izquierda. A este dinamismo también contribuyen sus brazos abiertos y los ricos plegados de las telas. Alrededor de su cabeza podemos distinguir un nimbo luminoso. Entre las bandas de nubes hay varias cabecitas de ángeles que harían las veces de escabel y asiento. En el ángulo superior derecho de la composición hallamos otras tantas cabecitas de querubines que dirigen

23 RÉAU, L.: Iconografía del arte cristiano. Iconografía de la Biblia, Tomo 1, Vol. 2 Barcelona, Ediciones Serbal, 1996, p. 638.

24 VILLEGAS, A.: Flos Sanctorum, historia general de la vida. y hechos de Jesu-Christo, Dios y Señor Nuestro, y de todos los santos, de que reza y hace fiesta la Iglesia católica. Madrid, Francisco del Hierro, 1721; citado por STRATTON, S.: La Inmaculada Concepción en el arte español. Madrid, FUE, 1989, p. 46.

25 RIBADENEIRA, P.: Flos Sanctorum o Libro de la Vida de los santos. Madrid, Luis Sánchez, 1616, pp. 557-558, 561

26 DOMÉNECH GARCíA, S.: "La recepción de la tradición hispánica de la Inmaculada Concepción en Nueva España: el tipo iconográfico de la Tota Pulchra", Espacio, tiempo y forma, Serie VII. Historia del Arte, no 3, 2015, p. 302. 
sus miradas hacia María. La figura de la Virgen es de una gran belleza, con un rostro muy delicado, lo que nos confirma que nos encontramos ante un artista bien formado y no ante un mero artesano.

De este mismo año es la edición del libro Relox perfecto de cuyos movimientos proceden las quince tiernas y devotísimas consideraciones pertenecientes a los mysterios del Santísimo Rosario $^{27}$, de fray Pedro de Santa María y Ulloa, que no sólo editó Pedro de la Rosa, sino que fue él quien financió la edición por su fervor por la Virgen María como se indica en la propia portada del libro. A diferencia de las dos anteriores estampas, la que ilustra este libro está firmada por Manuel Galicia de Villavicencio y en ella se representa a la Virgen del Rosario (Fig. 3).

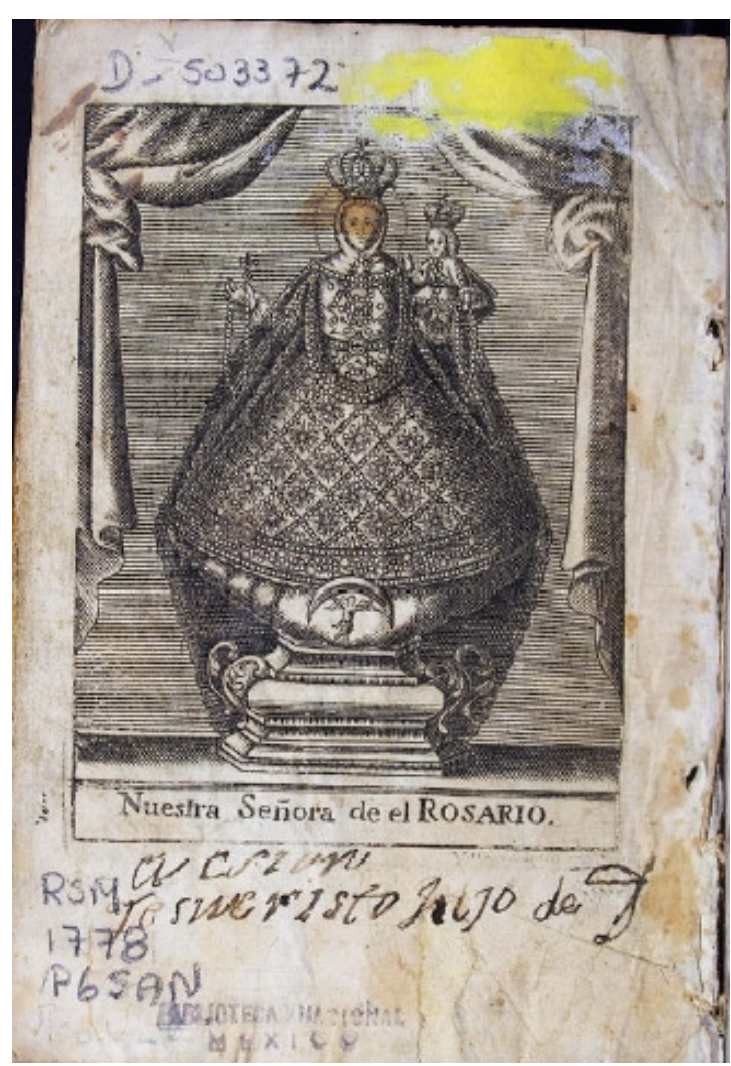

Sobre Villavicencio se sabe que estuvo activo entre 1753 y 1788 en la capital virreinal ${ }^{28}$. En ningún caso se le puede considerar un mero grabador, sino que fue un editor de estampas, entendiendo por tal, al empresario que asume todas las facetas vinculadas a la producción gráfica ${ }^{29}$. Participó en algunos de los grandes proyectos tipográficos realizados en Ciudad de México en la segunda mitad del siglo XVIII, lo que le llevó a colaborar con los más destacados impresores, entre los que podemos mencionar a Felipe de Zúñiga y Ontiveros, con quien colaboró en las Reales Exequias en honor de la reina Isabel de Farnesio de $1767^{30}$ o Las Ordenanzas de la división de la Nobilísima Ciudad de 1782, o con Joseph Antonio Hogal haciendo las estampas que ilustran el libro de Francisco Antonio Lorenzana, Historia de la Nueva España ${ }^{31}$ y las que ilustran los Concilios Provinciales primero y segundo, celebrados en la muy noble y leal ciudad de México de $1770^{32}$. Además Villavicencio realizó las estampas para varios impresos poblanos salidos del negocio de Pedro de la Rosa como
Fig. 3: Virgen del Rosario, en Relox perfecto de cuyos movimientos proceden las quince tiernas y devotísimas consideraciones pertenecientes a los mysterios del Santísimo Rosario, fray Pedro de Santa María y Ulloa. Manuel Galicia de Villavicencio, 1778. Biblioteca Nacional de México
28 DONAHUE-WALLACE, K.: Prints and printmakers in viceregal Mexico City. 1600-1800. Universidad de Nuevo México, 2000, pp. 84-85 (Tesis inédita); DONAHUE-WALLACE, K. "Printmakers in Eighteenth-Century Mexico City", Anales del Instituto de Investigaciones Estéticas, no 78, 2001, p. 231.

29 DONAHUE-WALLACE, K.: "Nuevas aportaciones sobre los grabadores novohispanos", Actas del III Congreso Internacional del Barroco Americano: territorio, arte, espacio y sociedad,.Sevilla, Universidad Pablo Olavide, 2001, p. 291.

30 BNM, Fondo Reservado, RFO 923.146ISAB.v

31 Biblioteca Nacional de España, Sala Cervantes, R/5625.

32 Biblioteca Central UNAM, Fondo Antiguo, BX837.M4 I2. 
las que ilustran la obra de Pablo Segneri, El infierno abierto al cristiano, para que no caiga en él o consideraciones de las penas que allá se padecen, del año $1785^{33}$. Aunque. como señaló Pérez Salazar, no se sabe si pudo trasladarse en algún momento a Puebla o si enviaba las planchas de cobre o las propias estampas desde la capital virreinal ${ }^{34}$.

La veneración por la Virgen del Rosario en la Nueva España tiene su origen en el momento de la conquista, siendo fundada la primera Cofradía del Rosario por el dominico fray Tomás de San Juan en $1538^{35}$. A fines del siglo XVII se construyó la famosa Capilla del Rosario en la iglesia de los dominicos de Puebla, una de las obras cumbre del Barroco novohispano, que demuestra la importancia de esta devoción y cómo se había extendido en la sociedad virreinal. Al igual que otras advocaciones marianas que vivieron un gran apogeo tras Trento, hunde sus raíces en la Edad Media. Los dominicos durante bastante tiempo pretendieron que la Virgen entregó el primer Rosario a santo Domingo en pleno siglo XIII, como medio eficaz para luchar contra la herejía albigense ${ }^{36}$, lo que explicaría el enorme auge que vivió esta advocación a partir del Concilio tridentino, por el carácter combativo contra los protestantes. Sin embargo, su creador fue el dominico bretón, Alain de la Roche que en 1470 escribió De Utilitate Psaterii Mariae, y en 1475 se estableció la primera Cofradía del Rosario en Colonia que fue aprobada en 1478 por el papa ${ }^{37}$. En 1571 el papa Pío V le

33 Biblioteca Nacional de Chile, Sala de microformatos, SM319.

34 PÉREZ SALAZAR, F.: op. cit., p. 37.

35 DÁVILA PADILLA, A.: Historia de la fundación y discurso de la Provincia de Santiago de México de la orden de los Predicadores. Bruselas, en casa de Juan de Meerbeque, 1625, p. 355.

36 RÉAU, L.: op. cit., p. 129; GONZÁLEZ LEYVA, A.: “Alegoría del Rosario", Cuadernos de Arte Colonial, $\mathrm{n}^{\circ}$ 3, octubre 1987, p. 97.

37 MÂLE, E.: L'art religieux de la fin du Moyen Age en France. París, Librairie Armand atribuyó al rezo del Rosario la victoria de la Liga Santa contra los turcos en Lepanto y un año después estableció la conmemoración de la Virgen de la Victoria que después Gregorio XVIII denominará Virgen del Rosario ${ }^{38}$. Esto nos indica la rápida implantación de este culto en la Nueva España, apenas setenta años después de su aparición en Europa.

En el margen inferior leemos esta inscripción: "Nuestra Señora del Rosario". Esta estampa parece reproducir una escultura de la Virgen del Rosario, lo que fue una práctica muy habitual en la Nueva España durante gran parte de la centuria. La Virgen se dispone sobre un alto pedestal, sobre el que se encuentra la luna creciente que sujeta un angelillo que es un atributo de la Mulier amicta sole, que generalmente se ha vinculado a la Inmaculada, pero como señaló García Mahíques, fue frecuente en las representaciones de la Virgen del Rosario ${ }^{39}$. En su mano derecha tiene un rosario, mientras que con la izquierda sostiene al Niño que también tiene un rosario en una de sus manos y con la otra señala a su Madre. La Virgen va ataviada con un vestido cubierto de piedras preciosas y una larga capa que cae hasta el suelo, sobre su cabeza hay una rica corona, al igual que el Niño. De los dos ángulos superiores caen unas cortinas anudadas en voluminosos plegados. Por desgracia la firma de Villavicencio está muy desgastada en la estampa con la que hemos trabajado, aunque técnicamente demuestra ser un artista sumamente hábil que domina perfectamente el procedimiento de la talla dulce.

Colin, 1949, p. 207; RÉAU, L.: op. cit, p. 130.

38 Ibídem; GONZÁleZ LEYVA, A.: op. cit., p. 98; SÁNCHEZ RIVERA, J. A.: “Culto y propaganda católica en torno a una pintura de la Virgen del Rosario", en Advocaciones Marianas de Gloria, San Lorenzo de El Escorial, 2012, p. 856.

39 GARCíA MAHíQUES, R.: "Perfiles iconográficos de la mujer del apocalipsis como símbolo mariano (I). Sicut mulier amicta sole et luna sub pedibus eius", Ars Longa, no 5, 1995, p. 195. 


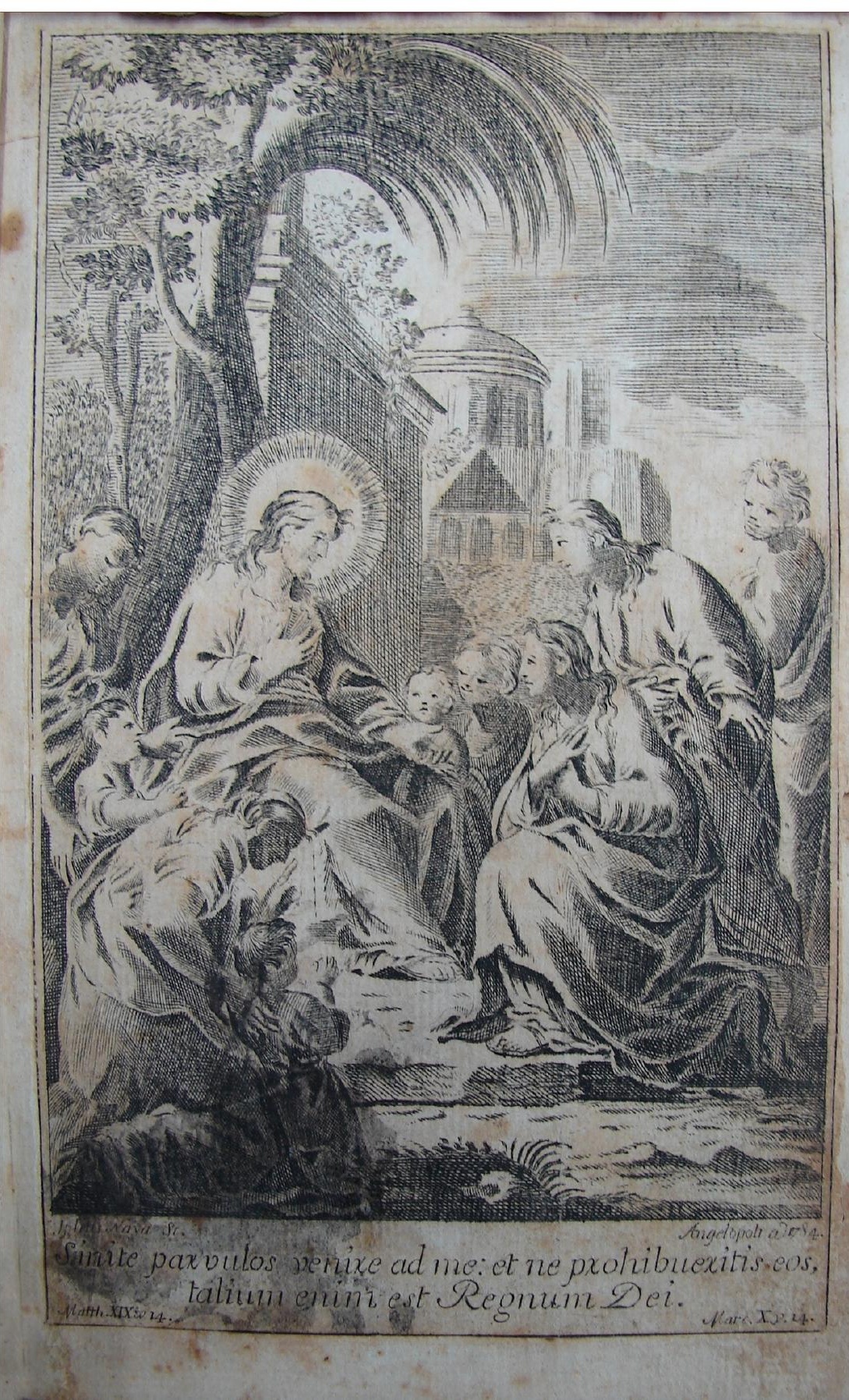

Fig. 4: Escena evangélica, Catecismo y exposición breve de la doctrina christiana, Jerónimo Ripalda. José de Nava, 1784. Biblioteca Nacional de México.

La siguiente estampa ilustra el libro del jesuita español Jerónimo Ripalda, Catecismo y exposición breve de la doctrina christiana ${ }^{40}$, editado en 1784 (Fig. 4). Como ya hemos señalado, en 1782 Pedro de la Rosa obtuvo un privilegio en la capital virreinal para imprimir los catecismos y doctrinas del padre Ripalda ${ }^{41}$. Además en el registro del libro Siestas dogmáticas, al que ya nos hemos referido, se incluye este libro ${ }^{42}$. Dicha estampa precede al "Privilegio de impresión" y está firmada por José de Nava y fechada en Angelopoli en 1784. A lo largo de la obra hallamos otras pequeñas estampas que se disponen al final de las distintas partes del libro, todas ellas firmadas por este artista, en las que se captan motivos decorativos con angelillos.

José de Nava ha sido considerado el grabador poblano más importante de la segunda mitad del siglo XVIII y de las primeras décadas del siglo $\mathrm{XIX}^{43}$. Aunque los datos biográficos que poseemos sobre él son muy escasos. Romero Terreros y Pérez Salazar consideran que nació hacia 1735, pero no proporcionan ninguna documentación que corrobore dicha fecha ${ }^{44}$. Este último en su trabajo sobre el grabado en Puebla, aporta su Acta de

40 BNM, Fondo Reservado, RSM 1784 P6RIP, Ejemplar 2

41 MARTínEZ PEÑALOZA, op. cit., p. 49; GARONE, M.: op. cit., pp. 434-435.

42 GONZÁLEZ DE LA ZARZA, J. A.: op. cit., sin paginar.

43 ROMERO DE TERREROS, M.: Grabados y grabadores en la Nueva España. México, Ediciones Arte Méxiano, 1948, p. 510; QUINTANA, J. M.: op. cit., pp. 19-20; PÉREZ SALAZAR, F.: op. cit., p. 39; DONAHUE-WALLACE, K.: "Los grabados de la biblioteca palafoxiana en la llustración", Miradas a la cultura del libro en Puebla. Bibliotecas, tipógrafos, grabadores, libreros y ediciones en la época colonial. México, Biblioteca Nacional de México y Conaculta, 2012, p. 357.

44 ROMERO DE TERREROS, M.: op. cit., p. 510; PÉREZ SALAZAR, F.: op. cit., p. 41. 
defunción del año $1817^{45}$. Su producción fue realmente enorme e incluye tanto obras religiosas como profanas, entre éstas podríamos destacar el mapa de la Nueva España dedicado al virrey Agustín de Ahumada y Villalón, fechado en 1755, o las dos estampas del Mapa de la suntuosa biblioteca del insigne Seminario Palafoxiano ${ }^{46}$ que se basaron en dibujos de Miguel Jerónimo Zendejas, del año 1773. Entre sus obras religiosas hay destacar una Vita gráfica de Santa Rosa de Viterbo ${ }^{47}$, formada por 33 estampas o la Missa Gothica seu mozarabica ${ }^{48}$. José de Nava abrió estampas que sirvieron para ilustrar los libros salidos de las dos principales imprentas poblanas de la segunda mitad del siglo XVIII, la de Pedro de la Rosa y la del Real Seminario Palafoxiano.

En la parte inferior de la estampa leemos una leyenda latina tomada de los evangelios de Mateo y Marcos: "Sinite párvulos venixe ad me: et ne prohibuexitis eos / talium enim est Regnum Dei. Matth. XIX, v. 14; Marc. X v. 14". En ella se representa la escena evangélica, en la que Cristo indica a sus discípulos que dejen que los niños se acerquen a él. La estampa está íntimamente unida al contenido del libro que está dedicado a la enseñanza y adoctrinamiento.

En el centro de la composición está Cristo sentado de perfil hacia la derecha, dirigiendo su mirada hacia un muchacho que está postrado delante de él, apoya una de sus manos en su pecho y la otra la extiende hacia el joven. Delante del Mesías hay una pareja conformada por el joven que está postrado en el suelo, mirando a Jesús, con sus manos cruzadas sobre su pecho en señal de recogimiento, y por otro muchacho que está de

45 Ibidem.

46 John Carter Brown Library, Providence, Rhode Island, OVERSIZE Me850.n322m.

47 John Carter Brown Library, Providence, Rhode Island, BA763.N316v.

48 BNM, Fondo Reservado, RSM 1770 P6IGL. pie que mira asombrado al Mesías, extendiendo una mano y con la otra recoge los voluminosos pliegues de su manto. En el extremo de la derecha hay un hombre de pie de tres cuartos de espaldas que gira su cabeza para mirar a Cristo, lo que genera una fuerte torsión en todo su cuerpo. En primer plano a la izquierda hay una mujer arrodillada de tres cuartos que se inclina hacia delante, apoyando una mano sobre la espalda de su hijo y con la otra señala a Jesús, para que el niño preste atención a la predicación. Éste está arrodillado y une sus manos en señal de oración y adoración. Estas figuras recuerdan a las de artistas flamencos de la anterior centuria como Abraham van Diepenbeeck, lo que nos lleva a pensar que José de Nava conoció la obra de este polifacético artista. En segundo término entre las figuras de Jesús y el joven que está arrodillado, se asoman las cabezas de un niño y su madre. En el extremo de la izquierda, a la espalda de Jesús, hay otra madre con su hijo, nuevamente ella trata de que su hijo atienda a la predicación de Cristo, mientras que el niño extiende una de sus manitas para tocar el manto de Jesús.

La escena tiene lugar en un paisaje con algunos árboles y algunos elementos arquitectónicos, como un alto pedestal sobre el que vemos la basa y el arranque del fuste liso de una columna. Al fondo hay un edificio rematado por una cúpula que se levanta sobre un tambor en el que se abren unos vanos.

Desde el punto de vista técnico, José de Nava demuestra un dominio absolutamente excepcional de la talla dulce, por ello tenemos que considerarle uno de los mejores grabadores novohispanos de su generación y de toda la centuria. A la hora de hacer las figuras, muestra una enorme habilidad para el dibujo, no hemos de olvidar la importancia que cobró la enseñanza del mismo en los estudios del arte del grabado en 
la Real Academia de San Carlos recién fundada en México en $1583^{49}$, aunque por desgracia desconocemos con quién se formó como dibujante. La luz juega un papel fundamental en el modelado de las telas, para ello crea una tupida red de rombos en las zonas en sombra, mientras que en las partes iluminadas emplea el blanco del papel.

La siguiente estampa ilustra el libro de Juan José Ramírez de Arellano que fue capellán mayor del Colegio de las Doncellas de Nuestra Señora de la Caridad de México, Novena al esclarecido mártir San Elías, que editó Pedro de la Rosa en Puebla en 1786 (Fig. 5) ${ }^{50}$. El objeto de este libro como se indica en el "Motivo de la Novena":

No es otro el motivo de la Señora Religiosa hija de san Elías, para sacar a luz esta Novena, que dar notica a los que no la tienen, de las sobre eminentes virtudes y excelencias de este esclarecido Patriarcha, para exercitar, y mover a los ánimos católicos a su devoción » $^{51}$.

Nuevamente nos encontramos ante una estampa que carece de las firmas del inventor, grabador y editor ${ }^{52}$. En la parte inferior hay una cartela con el nombre del santo con una rica decoración de roleos de clara raigambre barroca, hemos de tener en cuenta que el Barroco alcanzó su apogeo en la Nueva España en el siglo XVIII y perduró hasta bien avanzada la centuria,

49 DONAHUE-WALLACE, K.: "El grabado en la Real Academia de San Carlos de Nueva España, 1783-1810", Tiempos de América: revista de historia, cultura y territorio, $\mathrm{n}^{\circ} 11$, 2004, pp. 53-54.

50 Biblioteca Franciscana, convento de San Gabriel, provincia del Santo Evangelio, Universidad de las Américas de Puebla (UDLAP), Cholula, 3110COGE, Libro 11.

51 RAMÍREZ DE ARELLANO, J. J.: Novena al esclarecido mártir San Elías. Reimpresa en Puebla, Imprenta de Pedro de la Rosa, Portal de las Flores, 1786, sin paginar.

$52110 \times 81 \mathrm{~mm}$.

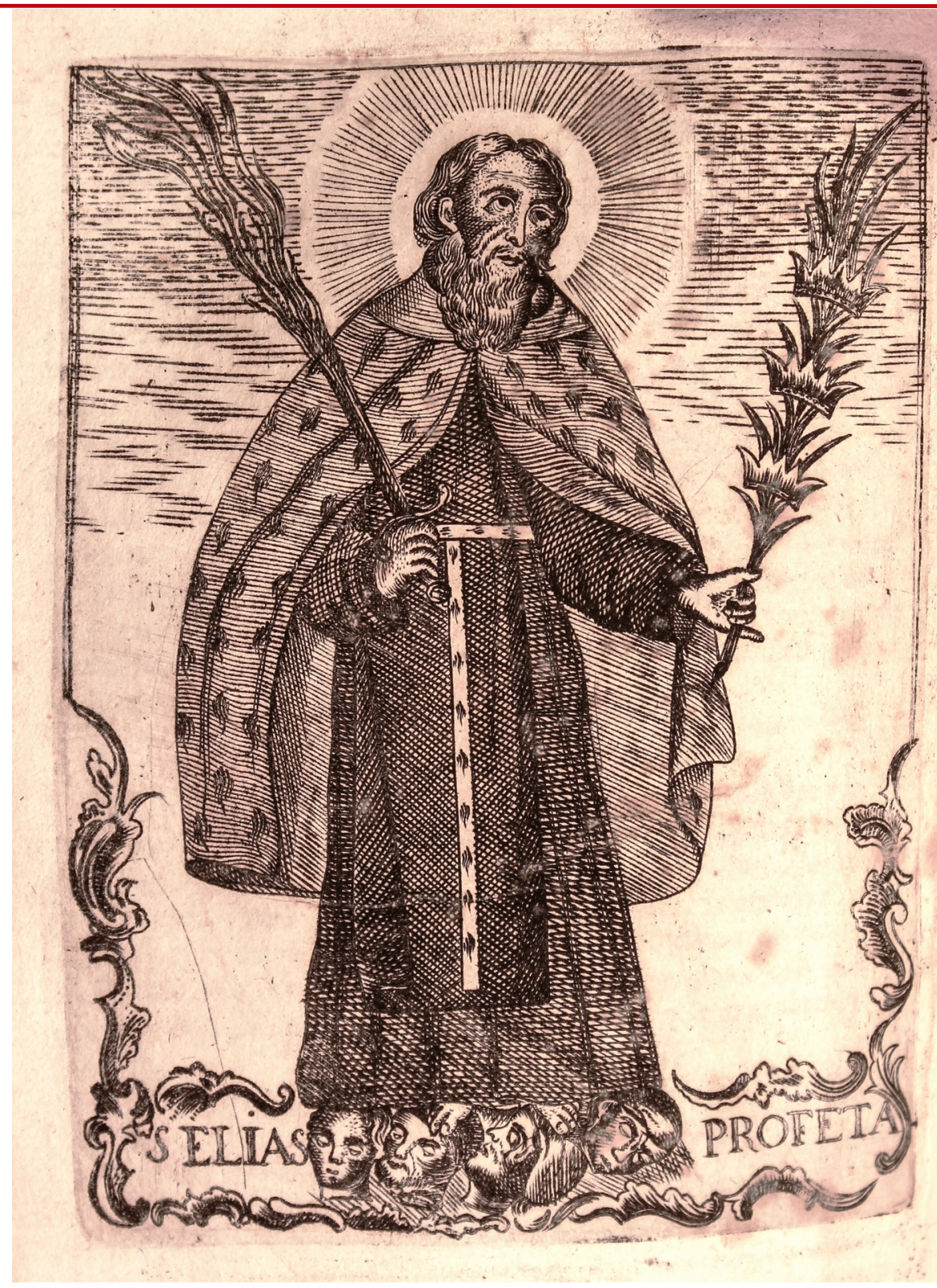

Fig. 5: San Elías, en Novena al esclarecido mártir San Elías, de Juan José Ramírez de Arellano, 1786. Biblioteca Franciscana, Convento de San Gabriel, Provincia del Santo Evangelio,

Universidad de las Américas de Puebla (UDLAP), Cholula 
cuando en Europa triunfaba el Neoclasicismo. La fundación de la Real Academia de San Carlos en México no supuso la desaparición definitiva del gusto barroco en Nueva España, sino que hubo unos años en los que pervivió junto con el clasicismo emanado de dicha institución. La leyenda queda dividida por las cabecitas que hacen las veces de pedestal para el profeta.

Elías fue considerado el fundador mítico de la Orden del Carmelo porque habitó en una gruta en el Monte Carmelo ${ }^{53}$, aunque en el "Motivo de la Novena" se va más allá y se le nombra el padre de todos los monjes, "porque él fue el primero, que se consagró a Dios con voto de obediencia, pobreza y castidad; que son los esenciales constitutivos del estado Religioso" ${ }^{\prime 54}$. Se trata de una figura de gran tamaño que se dispone sobre un fondo neutro y domina completamente la composición, va ataviado con el hábito carmelitano, tiene un cinturón y una capa decorados con unas Ilamitas porque fueron chamuscados en su ascensión al Cielo en el carro de $\operatorname{Dios}^{55}$. En su mano derecha porta una espada flamígera que haría referencia al sacrificio en el Monte Carmelo ${ }^{56}$ que va a ser uno de sus atributos más usuales y en la mano izquierda tiene una palma con tres coronas. Alrededor de su cabeza tiene un nimbo luminoso.

Técnicamente es una estampa de gran calidad, para captar el hábito color café carmelitano, el artista crea una tupida red de rombos, mientras que la capa de un tono más claro presenta unos trazos paralelos. Esto nos demuestra que nos hallamos ante un artista que conoce bien el procedimiento de la talla dulce, aunque la estampa carece de las firmas.

\footnotetext{
53 RÉAU, L.: op. cit., Tomo 1, Vol. 1, p. 401.

54 RAMÍREZ DE ARELLANO, J. J.: op. cit., sin paginar.

55 Libro Segundo de los Reyes, Cap. 2, 1-18.

56 Libro Primero de los Reyes, Cap. 18, 20-40. RÉAU, L.: op. cit., T. 1, Vol. 1, p. 403.
}

En el libro del jesuita José María Ignacio Genovesi y Tomay, La soledad christiana, en que a la luz del Cielo se consideran las eternas verdades. Según la idea de los Exercicios Espirituales de mi Santo Padre Ignacio, para los que desean por ocho días retirarse a ellos, impreso por Pedro de la Rosa en 1791 (Fig. 6) $)^{57}$, encontramos una estampa firmada por José de Nava. Esta misma estampa se empleó para ilustrar el segundo volumen de este libro que tiene por título, Lecciones espirituales para los ocho días de exercicios, editado ese mismo año ${ }^{58}$. Esta estampa tiene un gran parecido con una pintura conservada en la Capilla del Sagrario de la iglesia de san José de la propia ciudad de Puebla, que algunos han atribuido a Miguel Jerónimo Zendejas, aunque carece de firma (Fig. 7) ${ }^{59}$. Esta pintura forma parte de un conjunto de seis lienzos dispuestos a los pies de la capilla, bajo el coro; en dos de ellos se representan a los profetas Isaías y Jeremías, siendo este último el único que está firmado por Zendejas y fechado en 1782. Los otros cuatro lienzos están dedicados a san Ignacio de Loyola y san Francisco de Borja, siendo el que nos interesa aquel en el que vemos al fundador de la Compañía haciendo huir a unos demonios zoomorfos ${ }^{60}$, lo que supone una diferencia respecto a la estampa, en la que está combatiendo a un dragón.

La colaboración entre el pintor Miguel Jerónimo Zendejas y José de Nava tuvo uno de sus mejores ejemplos en las dos estampas de la Biblioteca

57 BNM, Fondo Reservado, RSM 1791 P6GEN, 81×123 mm.

58 Biblioteca Miguel Lerdo de Tejada, Fondo Reservado, 200/A80; Biblioteca Franciscana del Convento de san Gabriel de Cholula, UDLAP. 174COCA.

59 MONTERROSA PRADO, M.; TALAVERA SOLORZANO, L.: Catálogo Nacional de bienes muebles de la parroquia de san José de la ciudad de Puebla. Puebla, Gobierno del Estado de Puebla, 1991, p. 16.

60 MERLO JIMÉNEZ, E.; QUITANA heRnÁNDEZ, J. A.: Las iglesias de la Puebla de los Ángeles. Puebla, Secretaria de Cultura de Puebla, 2001, T. 1, pp. 139-140. 
Palafoxiana, fechadas en $1773^{61}$. Aunque esta estampa no tiene la firma del pintor, como si sucede en las de la famosa biblioteca poblana, es muy probable que se inspirase en la pintura o en un boceto previo de la misma. A diferencia de las estampas de la biblioteca que tenemos que enmarcar en el contexto de la llustración ${ }^{62}$, en este caso reproduce la pintura y se vincula estrechamente al contenido del libro centrado en enseñar a los fieles el uso de los Ejercicios Espirituales de Ignacio de Loyola que en ella aparece como campeón que lucha contra el demonio.

Para Donahue-Wallace en la formación de Zendejas tuvieron un papel muy destacado las estampas de reproducción europeas, pues su padre Lorenzo Zendejas viajó a Roma con el jesuita Juan Antonio Oviedo en 1716, como señala Bernardo Olivares Iriarte, y al parecer el jesuita le «(...) propuso al joven Lorenzo empleara alguna cantidad de dinero que él le proporcionaría en buenas estampas, que en su país expenderían con provecho de los artistas y estimación de los aficionados, conciliando de este modo el que le fuese también productivo el viaje. Se hizo por fin el acopio, ya de las conocidas de "humo" que entonces se hacían bajo protección del Instituto de la Compañía y ya de otras escogidas por los artífices con quienes estaban relacionados los jesuitas ${ }^{63}$.

61 Sobre los mismos resulta fundamental el estudio de DONAHUE-WALLACE, K.: "Los grabados de la biblioteca palafoxiana en la llustración", Miradas a la cultura del libro en Puebla. Bibliotecas, tipógrafos, grabadores, libreros y ediciones en la época colonial. México, Biblioteca Nacional de México y Conaculta, 2012, p. 355-376.

62 Ibidem, pp. 366-367.

63 OLIVARES IRIARTE, B.: Álbum artístico de 1855 http://digitalcollections.smu.edu/cdm/compoundobject/collection/mex/id/959/rec/1 fol. 42v (Consultado el 8/05/2017); citado por DONAHUE-WALLACE, K.: op. cit., 2012, pp. 372-373. Sobre dicho Album artístico resulta de gran interés el artículo de DONAHUE-WALLACE, K., Otro "Álbum artístico de Bernardo Olivares", Anales del Instituto de Investigaciones Estéticas, Vol. XXXVI, no. 105, 2014, pp. 187-214.
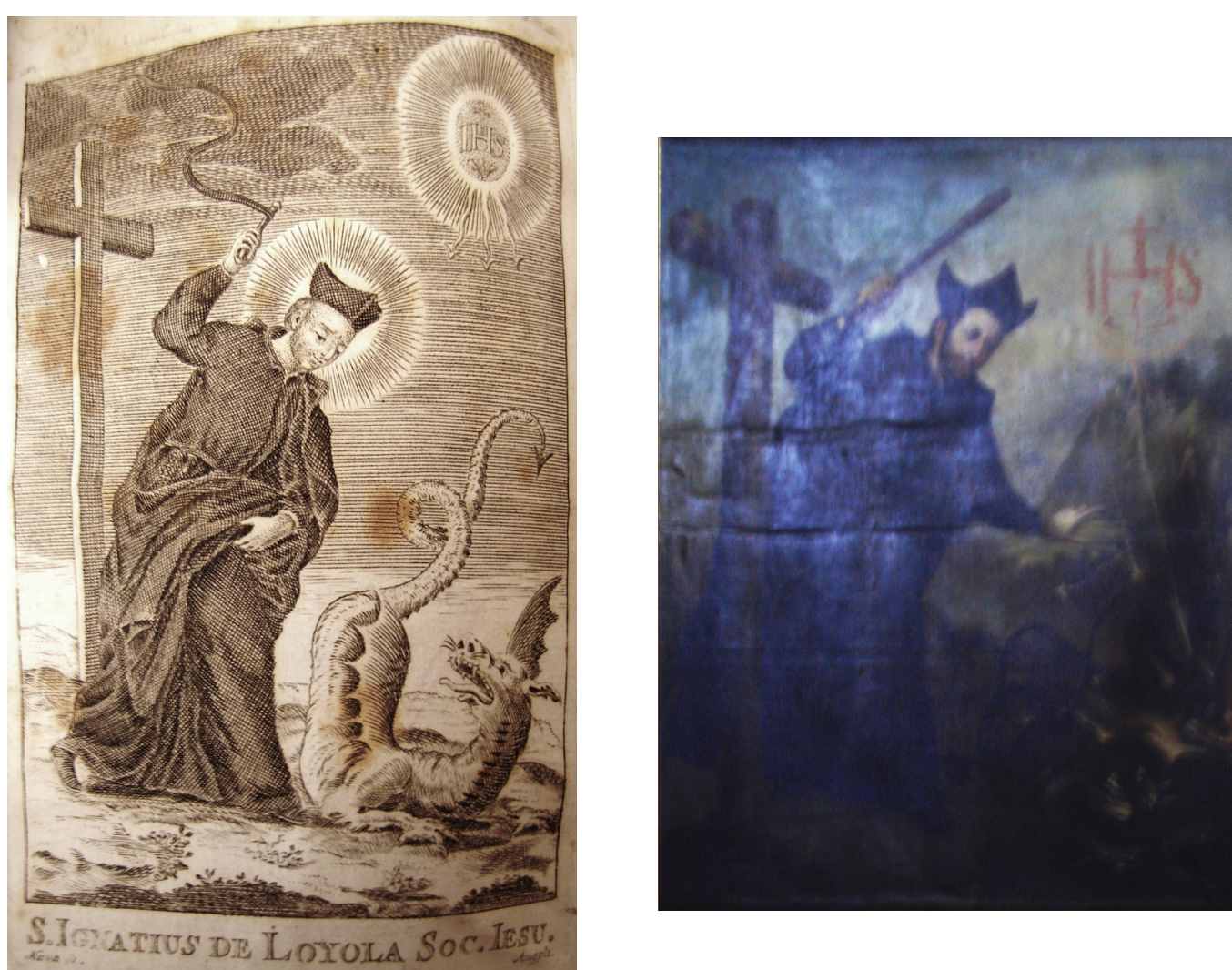

Fig. 6: San Ignacio derrotando al dragón, en La soledad christiana, en que a la luz del Cielo se consideran las eternas verdades. Según la idea de los Exercicios Espirituales de mi Santo Padre Ignacio, para los que desean por ocho días retirarse a ellos, José María Ignacio Genovesi y Tomay. José de Nava, 1791. Biblioteca Nacional de México

Fig. 7: San Ignacio derrotando a unos demonios. Capilla del Sagrario de la iglesia de san José de Puebla. Atribuido a Miguel Jerónimo Zendejas, h. 1782 
Olivares en este mismo documento señala que a su regreso a Puebla, Zendejas abrió un comercio dedicado a la venta de dichas estampas europeas ${ }^{64}$, lo que le diferencia de los típicos estamperos que se dedicaban a vender estampas devocionales. Además estas "buenas estampas" no estaban destinadas al público en general como las devocionales, sino a los propios artistas y a los aficionados. Por último, observamos que Lorenzo Zendejas tenía una estrecha relación con la Compañía de Jesús, lo que pudo beneficiar a su hijo al encontrar en los jesuitas a unos importantes mecenas y clientes.

Un poco más adelante Olivares Iriarte, dice:

“Cuando el niño Zendejas llegó a la edad de discernir se encontró rodeado de objetos que impresionarían fuertemente su ánimo, supuesto las disposiciones que tenía por la pintura (...) y estos bellos grabados que representaban las obras de Rubens, Ribera y Rafael lo embelesaron al término de formarle una inclinación irresistible por la pintura" ${ }^{65}$.

De estas palabras se colige que las estampas no sólo influyeron en su formación artística, sino que fueron las que le inclinaron a dedicarse a la pintura. En cualquier caso, el empleo de las estampas como medio para la formación artística no resulta novedoso y fue empleado tanto por artistas europeos como americanos. Es sumamente interesante que se cite entre las estampas que influyeron en Zendejas, las de tres grandes artistas dedicados a la estampa o cuyas obras fueron trasladadas al cobre. De Ribera de sobra es conocida su faceta de grabador, dando como resultado algunas de las obras cumbre de toda la historia del arte gráfico. Rubens

64 OLIVARES IRIARTE, B.: op. cit., fol. 43r; citado por DONAHUE-WALLACE, K.: op. cit., 2012, p. 373

65 OLIVARES IRIARTE, B.: op. cit., fol. 43r; citado por DONAHUE-WALLACE, K.: op. cit., 2012, p. 373. participó en algunos de los grandes proyectos gráficos realizados en Amberes en la primera mitad del siglo XVII, además en su taller trabajaban grabadores como los hermanos Bolswert, Lucas Vorsterman o Paulo Pontius, y sus estampas tuvieron un enorme predicamento en Nueva España. Por último, muchas de las obras de Rafael fueron trasladadas al cobre por Marcoantonio Raimondi o Giorgio Ghisi, entre otros.

La composición está dominada por la gran figura del fundador de la Compañía dispuesto de tres cuartos hacia la derecha, generado la sensación de estar avanzando hacia el dragón y va ataviado con la característica sotana negra de los jesuitas. Podemos apreciar algunas diferencias entre la figura del lienzo y de la estampa, en esta última el santo sostiene sobre su cabeza un látigo con el que va a fustigar al dragón, mientras que en la pintura es un garrote. En el lienzo extiende la mano izquierda de la que manan unos rayos con los que hiere a los demonios zoomorfos, mientras que en la estampa con dicha mano recoge los pliegues de su capa a la altura de su cintura. Tras el santo se encuentra la cruz como si la estuviera defendiendo de los ataques del demonio. Quizás la principal diferencia la hallamos en el dragón, que en el lienzo de la iglesia poblana son unos seres zoomorfos. Este dragón está a los pies del santo, presenta un marcado movimiento en todo su cuerpo, al levantar la cola como tratando de golpear al santo y girando su cabeza que remata en cresta similar a la de un gallo y abre sus fauces en actitud amenazante. Apreciamos cierto parecido, sobre todo por la forma de agitar la cola, con algunas representaciones de la Mulier amicta sole como la famosa estampa de Durero u otra estampa editada en Roma por Duchetti en pleno siglo XVI. En el ángulo superior derecho, al igual que en la pintura, se encuentra el emblema de la Compañía rodeado de resplandores que descienden en forma de rayos hacia el dragón, incidiendo en la lucha de los jesuitas contra el Demonio. Aunque en la pintura es muy difícil de apreciar, debido a la mala conservación, al fondo hay un agreste paisaje, que en la estampa se ha simplificado en unas pocas colinas. 
Fig. 8: Cristo en la cruz, Varias devotas y escogidas oraciones y exercicios espituales, 1793. Biblioteca Franciscana, convento de San Gabriel, provincia del Santo Evangelio, Universidad de las Américas de Puebla (UDLAP), Cholula

Dos años después Pedro de la Rosa publicó, Varias devotas y escogidas oraciones y exercicios espituales ${ }^{66}$, que está decorado por una pequeña entalladura anónima de Cristo en la cruz que precede a la dedicatoria (Fig. 8). La elección del motivo no resulta extraña, pues el libro se ofrece a Cristo crucificado como se desprende de las primeras palabras de la dedicatoria ${ }^{67}$. En esta misma se llama a los fieles a no olvidarse de venerar a Cristo y denuncia cierta inclinación por parte de los creyentes a sustituir el culto a Cristo por el de los santos ${ }^{68}$. La estampa anónima de pequeño formato, presenta un marco rectangular en el que hay un óvalo. La escena tiene lugar en un espacio indefinido, entre bandas de nubes a los lados. En el centro está la cruz rematada por el cartel del INRI. Cristo está colgado de la cruz por tres clavos, va ataviado con un paño de pureza anudado a un lado de su cintura. Sobre la cabeza tiene la corona de espinas y a su alrededor un nimbo luminoso. La estampa está muy desgastada como apreciamos en los trazos de la parte superior, lo que nos lleva a pensar que fue utilizada hasta su total agotamiento, práctica muy

66 Biblioteca Franciscana, Convento de san Gabriel de Cholula, UDLAP.193 COVE.

67 VV. AA.: Varias devotas y escogidas oraciones y exercicios espirituales. Puebla de los Ángeles, Imprenta de Pedro de la Rosa, 1793, pp. 1-2.

68 Ibidem, p. 4.

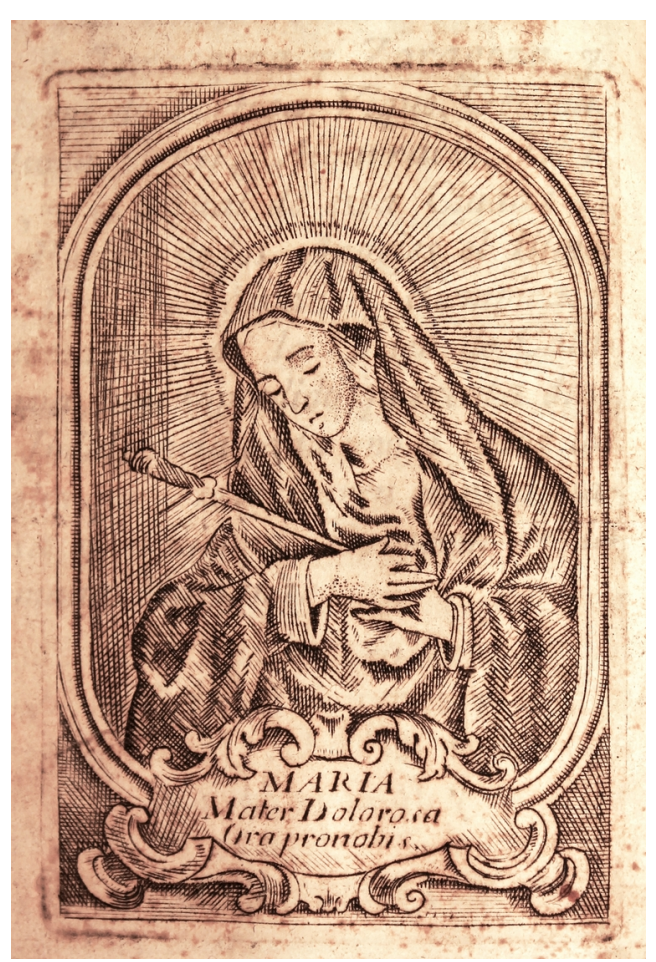

Fig. 9: Virgen de los Dolores, Obsequio a los dolores de María Santsima en la Pasión de su Hijo, Ignacio Vega y Caballero, 1802. Biblioteca Franciscana, convento de San Gabriel, provincia del Santo Evangelio, Universidad de las Américas de Puebla (UDLAP), Cholula

"MARIA / Mater recortados en la que leemos: ilustra un libro editado por el impresor poblano con la Virgen Dolorosa, lo que demuestra la extensión de esta advocación mariana.

69 Biblioteca Francisca, convento San Gabriel de Cholula, UDLAP. COCY3891K, 140×70 mm.

usual tanto en España como en las colonias. Por otra parte, se trata de una estampa de carácter eminentemente popular, sin ninguna pretensión artística.

Los dos últimos libros publicados por Pedro de la Rosa a los que nos vamos a referir, vieron la luz en la primera década del siglo XIX y los ejemplares con los que hemos trabajado pertenecen a los fondos de la Biblioteca Franciscana de Cholula. El primero de ellos es el libro, Obsequio a los dolores de María Santísima en la Pasión de su Hijo, de Ignacio Vega y Caballero, que fue editado en el año $1802^{69}$ Está decorado con una estampa anónima de la Dolorosa, abierta por el procedimiento de la talla dulce (Fig. 9). La figura se dispone dentro medallón ovalado, bajo el cual hay una cartela de cueros recortados en la que leemos: 
La Virgen está representada de medio cuerpo, levemente girada hacia la izquierda, apoyando delicadamente sus manos en su pecho, en el lugar en el que se clava la daga que aludiría a la profecía del sacerdote Simeón en el momento de la presentación del Niño en el Templo. Inclina suavemente la cabeza y en su rostro atisbamos claramente su dolor, al tener sus ojos casi cerrados y en su mejilla derecha una lágrima. Va vestida con unas telas de profundos plegados y cubre su cabeza con una toca que le cae sobre los hombros. Alrededor de su cabeza tiene un nimbo de rayos que se extienden a los lados.

Técnicamente es una estampa de una calidad excepcional, en su rostro y sus manos apreciamos el empleo de los ácidos y de las puntas con suaves toques. Las telas tiene unos pliegues voluminosos que logra combinando el blanco del papel, unas largas buriladas y en las zonas en sombra una tupida red de rombos. Como ya hemos señalado la estampa carece de firma, aunque es obvio que se debe a un artista consagrado, quizás José de Nava debido al parecido que tiene con algunas de sus obras. Además de que como venimos viendo colaboró asiduamente con Pedro de la Rosa.

La última estampa a la que nos vamos a referir se debe a José de Nava e ilustra el libro del jesuita Pablo Segneri, El Espejo que no engaña o la teoría y la práctica del conocimiento de sí mismo, editado en 1810 (Fig. 10) ${ }^{70}$. En la parte superior tiene una leyenda que hace las veces de título: "MATER INMACULATA". El motivo que se capta es el de la Inmaculada Concepción, cuya elección no es para nada fortuita, sino que tenemos que ponerla en relación con el propio autor que formaba parte de la Compañía de Jesús, que de sobra es sabida su defensa de la doctrina. Por otro lado, al final del libro, a modo de conclusión, el autor dedica unas palabras y una jaculatoria

70 Biblioteca Franciscana, convento de san Gabriel de Cholula, UDLAP. COGE3110A, $77 \times 114 \mathrm{~mm}$. a la Inmaculada, incidiendo en su papel de corredentora ${ }^{71}$. Como otras advocaciones marianas, la devoción por el misterio inmaculista arraigó prontamente en el territorio novohispano, siendo paralela al proceso de conquista y evangelización, prueba de ello es que la imagen de la Virgen en el estandarte de Hernán Cortés era una Inmaculada ${ }^{72}$. En la misma tuvieron un papel muy destacado las distintas órdenes religiosas, comenzando por los franciscanos, a los que se sumaron posteriormente los mercedarios, concepcionistas y jesuitas.

En este caso José de Nava opta por seguir el tipo iconográfico definitivo de la Inmaculada Concepción, surgido a fines del siglo XVI en España ${ }^{73}$. La Virgen está de pie sobre la luna creciente con las puntas hacia abajo, como señaló Pacheco en su famoso tratado ${ }^{74}$, aunque está ligeramente desplazada hacia la derecha, lo que provoca que los pies y las piernas de la Virgen tengan un marcado movimiento. Derrotada a sus pies está la serpiente sobre una banda de nubes, con una larga cola terminada en una aguda punta y entre sus fauces tiene la fruta del pecado, como clara referencia a la Ipsa del Génesis. La figura tiene un fuerte dinamismo en todo su cuerpo, apoya una mano sobre su pecho y la otra la extiende sosteniendo una vara de lirios que se toma de las Letanías marianas de origen medieval y va a ser uno de los emblemas más frecuentes en las representaciones inmaculistas, aunque en un primer momento aludía a la

71 SEÑERI, P.: El Espejo que no engaña o la teoría y la práctica del conocimiento de sí mismo. Puebla de los Ángeles, Imprenta de Pedro de la Rosa, 1810, pp. 92-94.

72 VARGASLUGO, E.: "Imágenes de la Inmaculada Concepción en la Nueva España", Anuario de Historia de la Iglesia, 2004, pp. 69-70, MARTínEZ, I.: "Estandarte de la monarquía española. El uso político de la Inmaculada Concepción", en La Concepción de María Inmaculada. La celebración del dogma en México, 2004, p. 126.

73 STRATTON, S.: op. cit., pp. 46-47.

74 PACHECO, F.: op. cit., p. 483 
virginidad de María. Alrededor de su cabeza tiene el nimbo de estrellas, tomado de la Mulier Amicta Sole, derivada de la narración del Apocalipsis (Ap. 12, 1), desde el cual se expanden unos rayos luminosos por toda la parte superior de la composición. La figura va ataviada con unas telas de una túnica con un cordoncillo anudado en el centro de su cintura y con un manto que le cae desde el brazo izquierdo en unos pliegues muy voluminosos que el viento parece agitar.

Desde el punto de vista técnico José de Nava demuestra un gran dominio de la talla dulce, que nos permite considerarle uno de los grabadores novohispanos más importantes de finales del período colonial. En el delicado rostro de la figura podemos apreciar cómo emplea tanto los ácidos como los suaves toques de las puntas. Combina el blanco del papel en las partes iluminadas, los largos trazos de los buriles en los rayos que manan del nimbo o una tupida red de rombos en los pliegues del manto y en las nubes que hacen las veces de pedestal que generan esa sensación de volumen y movimiento.

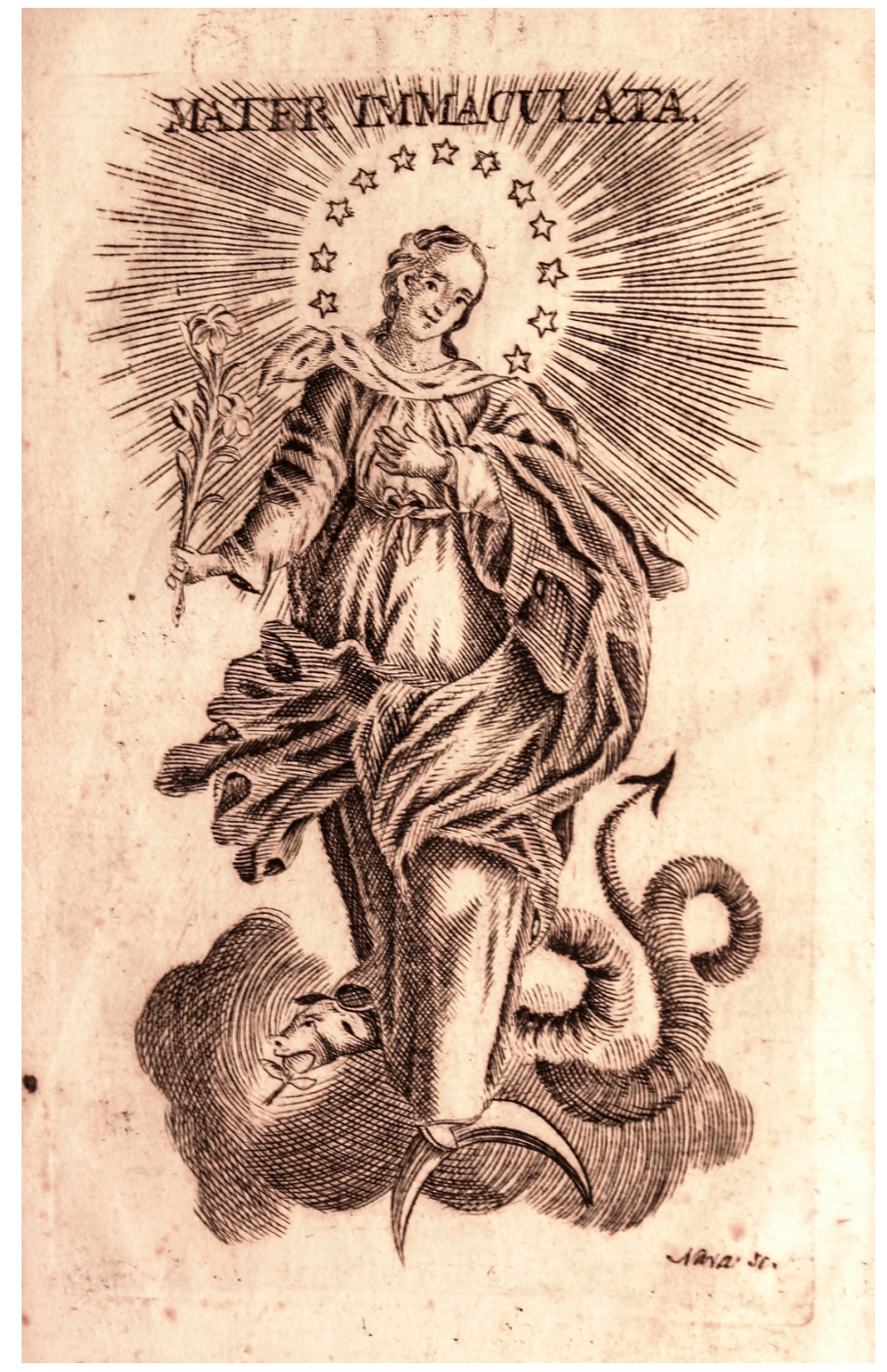

Fig. 10: Inmaculada Concepción, El Espejo que no engaña o la teoría y la prác tica del conocimiento de sí mismo, Pablo Segneri. José de Nava, 1810 Biblioteca Franciscana, convento de San Gabriel, provincia del Santo Evangelio, Universidad de las Américas de Puebla (UDLAP), Cholula

\section{CONCLUSIONES}

En este artículo hemos abordado el estudio iconográfico de algunas de las estampas que ilustraron ciertos libros publicados por la imprenta poblana de Pedro de la Rosa, desde el último cuarto del siglo XVIII a la primera década de la siguiente centuria. Entre los motivos que hemos hallado, destacan aquellos dedicados a diversas advocaciones marianas como la Dolorosa, la Virgen del Rosario o la Inmaculada Concepción, también hemos encontrado estampas con representaciones de santos como san Ignacio o san Elías, y algún que otro motivo evangélico. Ninguno de dichos motivos fue escogido aleatoriamente, sino que se relacionan con los propios contenidos de los libros o con los autores de los mismos.

Muchas de las estampas con las que hemos trabajado fueron abiertas por medio de la entalladura, demostrando cómo la aparición de la talla dulce en Puebla a fines del XVII, no hizo desaparecer dicho procedimiento. Por otro lado, muchas de ellas carecen de las correspondientes firmas del inventor, grabador $y$ editor, aunque algunas debido a su parecido técnico y estilístico se las hemos atribuido a José de Nava, el más importante grabador poblano de la centuria. Las pocas estampas firmadas nos han permitido apreciar la relación entre el impresor Pedro de la Rosa y los grabadores Manuel Galicia de Villavicencio y José de Nava, aunque fue este último el que trabajó de forma más habitual con él. 


\section{BIBLIOGRAFÍA}

BARGELLINI, $\mathrm{Cl}$ :: "Jesuits devotions and Retablos in New Spain", en The Jesuits. Cultures, Sciences and the Arts. 1540-1773. Toronto, University of Toronto Press, 2000, pp. 680-698.

: "El arte en las misiones del norte de la Nueva España", en el catálogo de la exposición El arte en las misiones del Norte de la Nueva España. Ciudad de México, Antiguo Colegio de san Ildefonso, 2009, pp. 54-93.

CASTILLO OREJA, M. Á.; GORDO PÉLAEZ, L. J.: "Versos e imágenes: culto y devociones marianas en el templo de la Compañía de Jesús en Zacatecas, México", Anales de Historia del Arte, 2008, № Extraordinario, pp. 307-339.

DÁVILA PADILLA, A.: Historia de la fundación y discurso de la Provincia de Santiago de México de la orden de los Predicadores. Bruselas, en casa de Juan de Meerbeque, 1625.

DE ABREU, J.: Desagravios dolorosos de la Santísima Virgen María Nuestra Señora, por los agravios ignominiosos de Christo Nuestro Redentor, "Prólogo al lector". Puebla de los Ángeles, Imprenta de los herederos de la viuda de Miguel Ortega, 1774.

DOMÉNECH GARCÍA, S.: "La recepción de la tradición hispánica de la Inmaculada Concepción en Nueva España: el tipo iconográfico de la Tota Pulchra", Espacio, tiempo y forma, Serie VII. Historia del Arte, no 3, 2015, pp. 275-309.

DONAHUE-WALLACE, K.: Prints and printmakers in viceregal Mexico City. 1600-1800. Universidad de Nuevo México, 2000, (Tesis inédita).
: "Printmakers in Eighteenth-Century Mexico City", Anales del Instituto de Investigaciones Estéticas, no 78, 2001, pp. 221-234.

: "Nuevas aportaciones sobre los grabadores novohispanos", Actas del III Congreso Internacional del Barroco Americano: territorio, arte, espacio y sociedad. Sevilla, Universidad Pablo Olavide, 2001, pp. 290 297.

: "El grabado en la Real Academia de San Carlos de Nueva España, 1783-1810", Tiempos de América: revista de historia, cultura y territorio, $\mathrm{n}^{\circ} 11,2004$, pp. 49-61.

: "Los grabados de la biblioteca palafoxiana en la llustración", Miradas a la cultura del libro en Puebla. Bibliotecas, tipógrafos, grabadores, libreros y ediciones en la época colonial. México, Biblioteca Nacional de México y Conaculta, 2012, pp. 355-376.

: Otro "Álbum artístico de Bernardo Olivares", Anales del Instituto de Investigaciones Estéticas, Vol. XXXVI, no. 105, 2014, pp. 187-214.

GARCÍA MAHÍQUES, R.: "Perfiles iconográficos de la mujer del apocalipsis como símbolo mariano (I). Sicut mulier amicta sole et luna sub pedibus eius", Ars Longa, no 5, 1995, pp. 187-197.

GARONE GRAVIER, M.: Historia de la imprenta y la tipografía colonial en Puebla de los Ángeles. Ciudad de México, UNAM, Instituto de Investigaciones Bibliográficas, 2014.

GONZALBO AIZPURU, P.: “Las devociones marianas en la vieja provincia de 
la Compañia de Jesús", en Manifestaciones religiosas en el mundo colonial americano, Vol. 2, Mujeres, instituciones y culto a María. Ciudad de México, Universidad Iberoamericana, INAH, Codumex, 1994, pp. 105-116.

GONZÁLEZ DE LA ZARZA, J. A.: Siestas dogmáticas en las que con un estilo dulce, claro y llano por un niño es instruido un ranchero en las quatro partes principales de la doctrina christiana. Puebla, Imprenta de Pedro de la Rosa.

GONZÁLEZ LEYVA, A.: "Alegoría del Rosario", Cuadernos de Arte Colonial, n 3, octubre 1987, pp. 93-101.

MÂLE, E.: L'art religieux de la fin du Moyen Age en France. París, Librairie Armand Colin, 1949.

MARTÍNEZ, I.: "Estandarte de la monarquía española. El uso político de la Inmaculada Concepción", en La Concepción de María Inmaculada. La celebración del dogma en México. Ciudad de México, Museo de la Basílica de Guadalupe, 2005, pp. 123-154.

MARTÍNEZ PEÑALOZA, T.: "Atisbos del barroco mexicano", Imprentas, ediciones y grabados de México Barroco. Puebla, Museo Amparo, 1995.

MEDINA, J. T.: La imprenta en la Puebla de los Ángeles. Ciudad de México, Universidad Nacional Autónoma de México, 1991.

MERLO JIMÉNEZ, E.; QUITANA HERNÁNDEZ, J. A.: Las iglesias de la Puebla de los Ángeles. Puebla, Secretaria de Cultura de Puebla, 2001.
MONTERROSA PRADO, M.; TALAVERA SOLORZANO, L.: Catálogo Nacional de bienes muebles de la parroquia de san José de la ciudad de Puebla. Puebla, Gobierno del Estado de Puebla, 1991.

OLIVARES IRIARTE, B.: Álbum artístico de 1855, http://digitalcollections.smu.edu/cdm/compoundobject/collection/m ex/id/959/rec/1

PACHECO, F.: Arte de la pintura. Sevilla, Simón Faxardo, 1649.

PÉREZ SALAZAR, F.: El grabado en la ciudad de Puebla de los Ángeles. Puebla, Gobierno del Estado de Puebla, Secretaria de Cultura, 1990.

QUINTANA, J. M.: Las artes gráficas en Puebla. México, Antigua Librería Robredo, 1960.

RAGON, P.: "Imprentas coloniales e historia de las devociones en México (Siglos XVII y XVIII)", REDIAL: revista europea de información y documentación sobre América Latina, № 8-9, 1998, pp. 33-42.

RAMÍREZ DE ARELLANO, J. J.: Novena al esclarecido mártir San Elías. Reimpresa en Puebla, Imprenta de Pedro de la Rosa, Portal de las Flores, 1786.

RÉAU, L.: Iconografía del arte cristiano. Iconografía de la Biblia, Tomo 1, Vol. 2. Barcelona, Ediciones Serbal, 1996.

RIBADENEIRA, P.: Flos Sanctorum o Libro de la Vida de los santos. Madrid, Luis Sánchez, 1616. 
ROMERO DE TERREROS, M.: Grabados y grabadores en la Nueva España. México, Ediciones Arte Méxicano, 1948.

SÁNCHEZ RIVERA, J. A.: "Culto y propaganda católica en torno a una pintura de la Virgen del Rosario", en Advocaciones Marianas de Gloria, San Lorenzo de El Escorial, 2012, pp. 851-866.

SEÑERI, P.: El Espejo que no engaña o la teoría y la práctica del conocimiento de sí mismo. Puebla de los Ángeles, Imprenta de Pedro de la Rosa, 1810.

STRATTON, S.: La Inmaculada Concepción en el arte español. Madrid, FUE, 1989.

VARGASLUGO, E.: "Imágenes de la Inmaculada Concepción en la Nueva España”, Anuario de Historia de la Iglesia, 2004, pp. 67-78.

VILLEGAS, A.: Flos Sanctorum, historia general de la vida. y hechos de JesuChristo, Dios y Señor Nuestro, y de todos los santos, de que reza y hace fiesta la Iglesia católica. Madrid, Francisco del Hierro, 1721.

VV. AA.: Varias devotas y escogidas oraciones y exercicios espirituales. Puebla de los Ángeles, Imprenta de Pedro de la Rosa, 1793. 